This Accepted Author Manuscript is copyrighted and published by Elsevier. It is posted here by agreement between Elsevier and University of Brasilia. Changes resulting from the publishing process - such as editing, corrections, structural formatting, and other quality control mechanisms - may not be reflected in this version of the text. The definitive version of the text was subsequently published in [Tissue and Cell, Volume 31, Issue 3, June 1999, Pages 308-317, doi:10.1054/tice.1999.0047].You may download, copy and otherwise use the AAM for noncommercial purposes provided that your license is limited by the following restrictions:

(1) You may use this AAM for non-commercial purposes only under the terms of the CC-BY-NCND license.

(2) The integrity of the work and identification of the author, copyright owner, and publisher must be preserved in any copy.

(3) You must attribute this AAM in the following format: [agreed attribution language, including link to CC BY-NC-ND license + Digital Object Identifier link to the published journal article on Elsevier's ScienceDirect ${ }^{\circledR}$ platform].

Este Manuscrito do Autor Aceito para Publicação (AAM) é protegido por direitos autorais e publicado pela Elsevier. Ele esta disponível neste Repositório, por acordo entre a Elsevier e a Universidade de Brasília. As alterações decorrentes do processo de publicação - como a edição, correção, formatação estrutural, e outros mecanismos de controle de qualidade - não estão refletidas nesta versão do texto. A versão definitiva do texto foi posteriormente publicado em [Tissue and Cell, Volume 31, Número 3, Junho de 1999, Páginas 308-317, doi:10.1054/tice.1999.0047]. Você pode baixar, copiar e utilizar de outra forma o AAM para fins não comerciais , desde que sua licença seja limitada pelas seguintes restrições:

(1) Você pode usar este AAM para fins não comerciais apenas sob os termos da licença CC- BYNC-ND.

(2) A integridade do trabalho e identificação do autor, detentor dos direitos autorais e editor deve ser preservado em qualquer cópia.

(3) Tem de atribuir este AAM no seguinte formato: [acordo na linguagem atribuída, incluindo o link para CC BY-NC-ND licença Digital + DOI do artigo publicado na revista Elsevier ScienceDirect ${ }^{\circledR}$ da plataforma]. 


\title{
Ultrastructural study of spermatozoa of the neotropical lizards, Tropidurus semitaeniatus and Tropidurus torquatus (Squamata, Tropiduridae)
}

\author{
R.D. Teixeira \\ G.H.C. Vieira \\ G.R. Colli \\ S.N. Báo
}

\begin{abstract}
A detailed description of the sperm ultrastructure of Tropidurus semitaeniatus and $\mathrm{T}$. torquatus is provided. Mature spermatozoa of T. semitaeniatus and T. torquatus are filiform and characterized by: apical portion of acrosome depressed; perforatorium single; epinuclear lucent zone well developed; midpiece short; mitochondria columnar; midpiece with three sets of alternating ring structures and mitochondria ( $\mathrm{rs} 1 / \mathrm{m} 1, \mathrm{rs} 2 / \mathrm{m} 2, \mathrm{rs} 3 / \mathrm{m} 3)$; nuclear shoulders rounded; nucleus elongate; fibres 3 and 8 enlarged; and fibrous sheath in midpiece. Spermatozoa ofTropidurus are unusual in possessing a unilateral electron-lucent ridge at the surface of the acrosome and an epinuclear electron-lucent zone. The two species are very similar, differing in details such as degree of acrosome flattening, presence of bulging at nuclear base, and arrangement of microtubules in the endpiece. Comparisons between Tropiduridae and other families of iguanian lizards are made.
\end{abstract}

Keywords: ultrastructure, spermatozoon, Reptilia, Squamata, Tropiduridae, lizard

\section{Introduction}

Studies on the ultrastructure of spermatozoa have fostered knowledge on the development and functional significance of many spermatozoal organelles (Stanley, 1971), elucidating the relationship among these components and reproduction itself (Cruz-Landim \& Cruz-Höfling, 1977). Detailed accounts on the ultrastructure of spermatozoa also supply an independent source of characters for phylogenetic analyses, which are especially useful when other character sets are not enlightening (Jamieson, 1995a; 1995b; Teixeira et al., 1999a). Moreover, phylogenetic studies may provide a framework for reconstructing the features of ancestral spermatozoa and the course of spermatozoal evolution, establishing the relationship between sperm morphology and systematic position.

Iguania is a monophyletic assemblage of nine families of squamate reptiles whose phylogenetics relationships are poorly understood (Frost \& Etheridge, 1989). Studies on the sperm ultrastructure have been carried out in five families of iguanians: Chamaeleonidae, Iguanidae, Phrynosomatidae, Polychrotidae, and Tropiduridae. In Chamaeleonidae, the mature spermatozoon has been described in detail for Bradypodion karrooicum (Jamieson, 1995b) and 
Pogona barbata (Oliver et al., 1996), whereas the spermiogenesis has been examined in Agama stellio (Al-Hajj et al., 1987), A. adramitana (Dehlawi et al., 1992; Ismail et al., 1995), and Uromastyx philbyi (Dehlawi \& Ismail, 1990; Dehlawi et al., 1990). A description of the spermiogenesis is available for Iguana iguana (Iguanidae), misidentified as I. delicatissima, by Saita et al. (1988). A few details of the spermiogenesis are known for a member of Phrynosomatidae, Phrynosoma coronatum (Clark, 1967). In Polychrotidae, Teixeira et al. (submitted) gave a detailed account on the ultrastructure of mature spermatozoa of Polychrus acutirostris, Furieri (1974) described the mature spermatozoon of Pristidactylus (=Cupriguanus) scapulatus, and Clark (1967) described the spermiogenesis of Anolis carolinensis. Among Tropiduridae, the mature spermatozoon of Liolaemus austromendocinus and Phymaturus flagellifer (=palluma) have been described (Furieri, 1974), and an account on the spermiogenesis of Tropidurus cf. torquatus is available (Cruz-Landim \& Cruz-Höfling, 1977; Cruz-Höfling \& Cruz-Landim, 1978).

Herein we provide, for the first time, a detailed description of the ultrastructure of mature spermatozoa of Tropiduridae. We also make comparisons between tropidurids and other iguanian families. Finally, by examining two congeneric species, we attempt to ascertain the degree of intrafamilial variability in sperm ultrastructure characters, a problem that may plague phylogenetic analysis when supraspecific taxa are used, but has received little attention (Wiens, 1998).

\section{Materials and methods}

We obtained epididymal, mature spermatozoa from two adult specimens of Tropidurus semitaeniatus and two adult specimens of T. torquatus, collected at Lençóis, Bahia, Brazil and Brasília, Distrito Federal, Brazil, respectively. Specimens were deposited at the Coleção Herpetológica da Universidade de Brasília (T. semitaeniatus CHUNB 00571, 00572; T. torquatus CHUNB 09676, 10087).

We killed the lizards with Tiopental, removed the epididymides by dissection, placed them in a Petri dish with phosphate buffered saline (PBS) pH 7.2, and cut them into small pieces. We fixed epididymal tissues overnight at $4^{\circ} \mathrm{C}$ in a solution containing $2.5 \%$ glutaraldehyde, $2 \%$ paraformaldehyde, and $3 \%$ sucrose in $0.1 \mathrm{M}$ sodium cacodylate buffer $\mathrm{pH}$ 7.2. Subsequently, we washed specimens in $0.1 \mathrm{M}$ sodium cacodylate buffer, $\mathrm{pH} 7.2$, with $3 \%$ sucrose, and postfixed them for $1 \mathrm{~h}$ in $1 \%$ osmium tetroxide, $0.8 \%$ potassium ferricyanide, and $5 \mathrm{mM} \mathrm{CaCl} 2$ in $0.1 \mathrm{M}$ sodium cacodylate buffer, $\mathrm{pH}$ 7.2. We dehydrated the material in a series of ascending acetone (30\%-100\%) and embedded it in Spurr's epoxy resin. We stained 
ultrathin setions with uranyl acetate and lead citrate, and made observations in a Jeol $100 \mathrm{C}$ transmission electron microscope.

\section{Results}

Spermatozoa of Tropidurus semitaeniatus and T. torquatus are filiform, consisting of a head region containing the nucleus and the acrosomal structures, a midpiece, and a tail region subdivided into principal piece and endpiece. A generalized spermatozoon based on both species is represented diagrammatically in Figure 1.

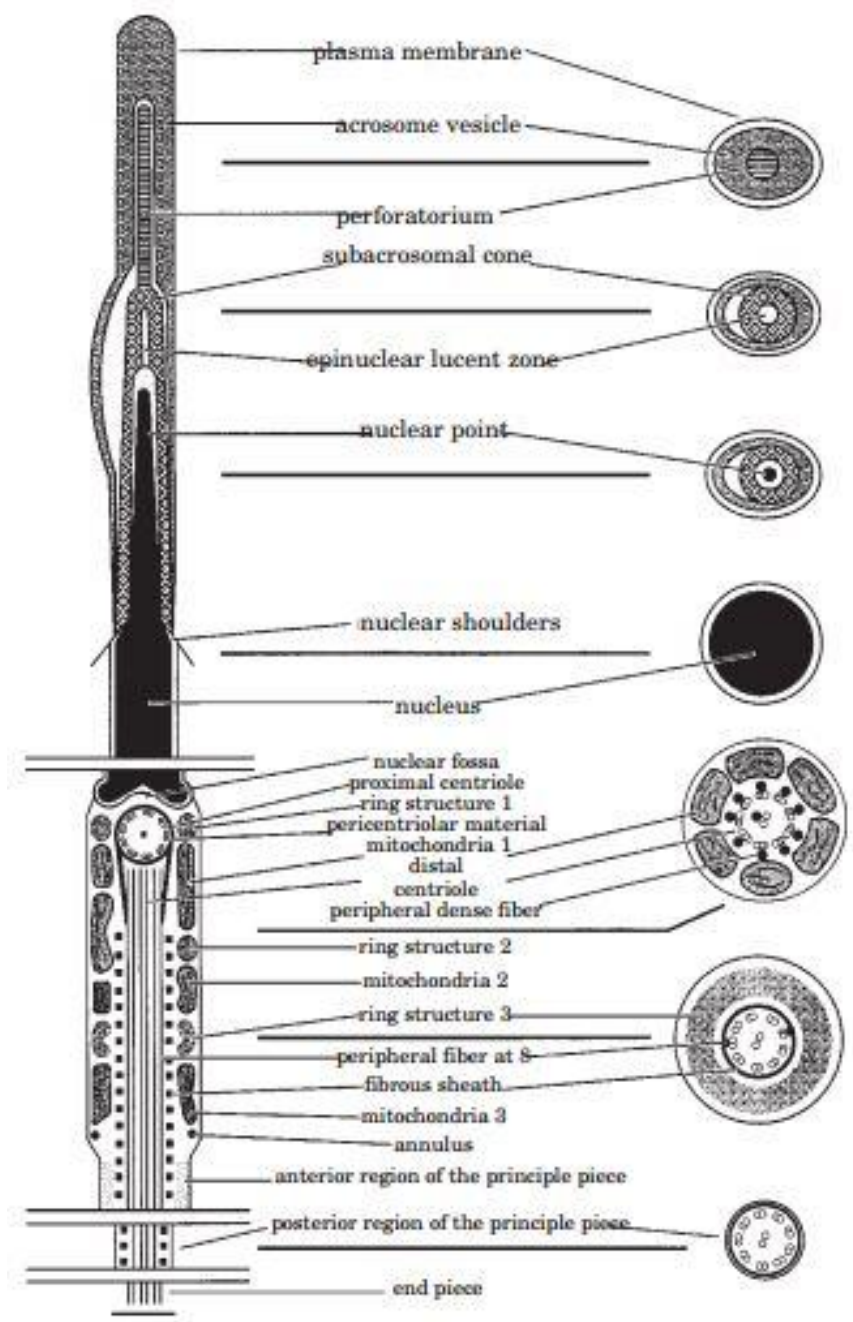

Fig. 1 Generalized diagram of the spermatozoon of Tropidurus semitaeniatus and T. torquatus, in longitudinal section and corresponding transverse section. Scales of various components are only approximate. Scale bar $0.5 \mu \mathrm{m}$

\section{Acrosome complex}

In the acrosome, an external and an internal cap, the acrosome vesicle and the subacrosomal cone, respectively, are recognized (Figs $2 A-B, H \& 4 A-B, H$ ). The acrosome 
vesicle has a homogeneous and moderately opaque matrix, bounded both outside and inside by a membrane (Figs $2 A-F, H \& 4 D-F, H$ ). The acrosome vesicle is thicker in its apical half, whereas the basal half is hollowed to surround the subacrosomal cone. The apical portion of the acrosome vesicle is not completely solid, having a narrow central canal $1.2 \mu \mathrm{m}$ long, the perforatorium (Figs $2 A, C, H \& 4 A-C$ ). This structure is a slender rod with a pointed tip, which extends anteriorly from the subacrosomal cone. The subacrosomal cone fits into the basal half of the acrosome vesicle, being shorter and thicker than the latter, and lacks a membrane of its own (Figs $2 A-B, D-F, H$ \& 4D-F, H). It consists of a material having an unevenly aspect, which tapers the anterior end of the nucleus. The subacrosomal cone surface is closely associated with the inner membrane of the acrosome vesicle, except at its apical and anterolateral surface, where an electron-lucent layer separates these two caps, forming a unilateral ridge (Figs 2B \& 4H). At its base, the acrosome complex rests on a widening region of the nucleus with a distinct shoulder-like shape, lying on a postero-lateral membranous flange (Figs $2 \mathrm{H} \&$ $4 \mathrm{H})$. The acrosome of the two species is circular at its base, develops an unilateral electronlucent ridge anteriorly, and becomes increasingly depressed in transverse section near the apical tip (Figs $2 \mathrm{C}-\mathrm{F} \& 4 \mathrm{C}-\mathrm{F}$ ). Apically, the acrosome vesicle of $\mathrm{T}$. torquatus is more depressed than that of T. semitaeniatus (Figs $4 C \& 2 C$ ).

\section{Nucleus}

The nucleus is elongate, slightly curved, and circular in cross-section. At its anterior extremity, it forms a point deeply wedged in the acrosome (Figs $2 \mathrm{H} \& 4 \mathrm{H}$ ). The length of this nuclear projection, which is surrounded by the subacrosomal cone, is approximately $2.5 \mu \mathrm{m}$. Anterior to the nuclear tip and within the subacrosomal cone there is an elongate, narrow chamber with a membrane of its own, the epinuclear lucent-zone, filled with an electronlucent substance (Figs 2D, H \& 4D, H). Small rounded shoulders (Figs 2B, H \& 4H) mark the transition from the tapered apical portion to the cylindrical region. The posterior pole of the nucleus is marked by a shallow conical depression, the nuclear fossa, for receiving the centriolar apparatus (Figs 3A, H, I \& 5A, I). The main body of the nucleus appear homogeneous and completely electron-dense, but in some instances there are small, electron-lucent channels penetrating it, the lacunae (Figs $2 G \& 4 G$ ). Along the nuclear point the boundary between the nuclear contents and the nuclear envelope is irregular, containing evenly dispersed, fine granular material (Figs 2B, E-F, H \& 4B, E-F, H). In T. semitaeniatus, the nuclear base abruptally increases in width, producing a conspicuous, rounded bulge (Fig. $3 \mathrm{~A}$ ), which is absent in T. torquatus (Figs $4 \mathrm{H} \& 5 \mathrm{I}$ ). 


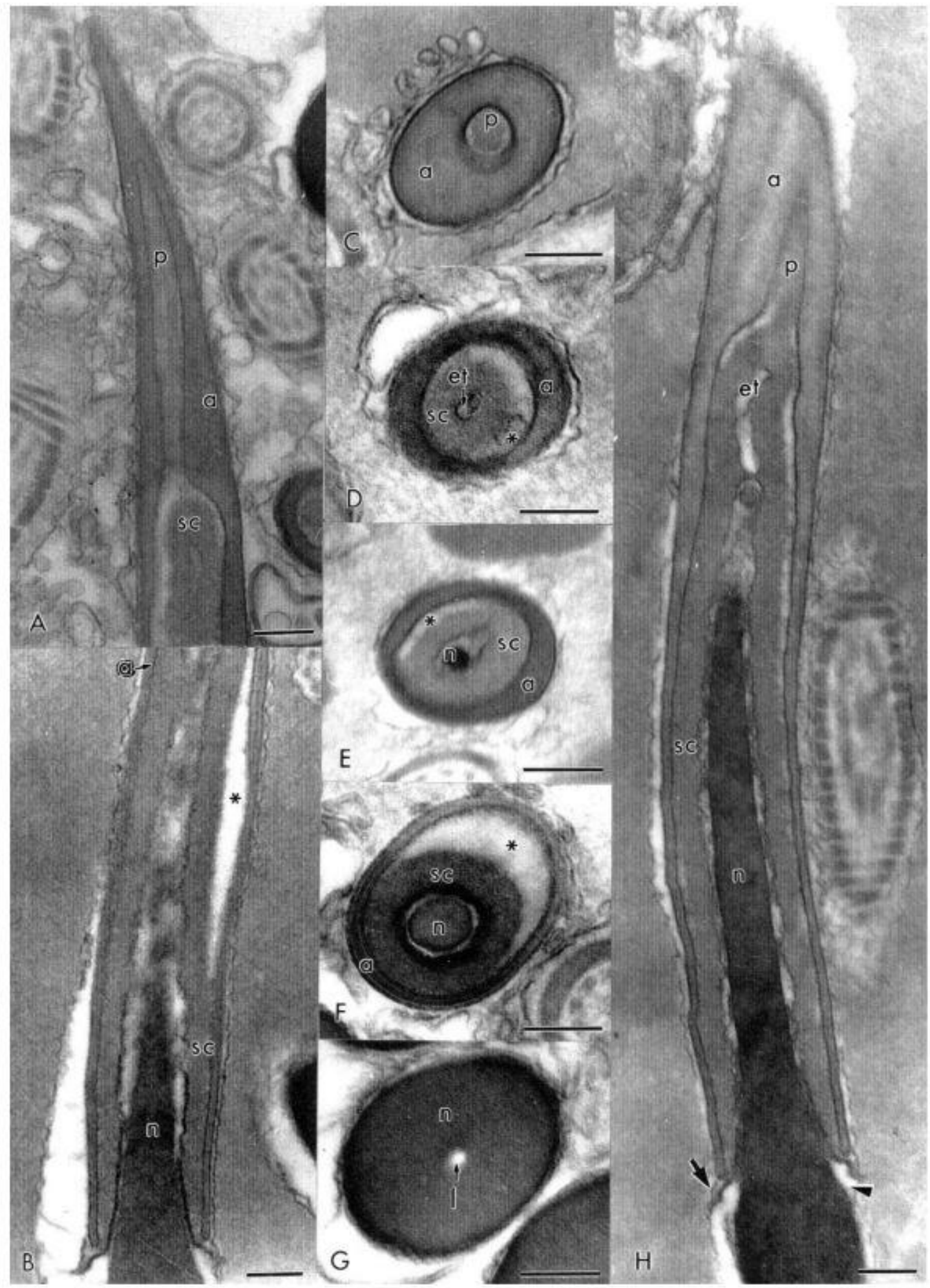

Fig. 2 Tropidurus semitaeniatus. (A) Longitudinal section through the apical end of the acrosome showing the perforatorium. (B) Longitudinal section through the basal portion of the acrosome showing the unilateral ridge, formed by an electron-lucent layer $\left({ }^{*}\right)$ between the acrosome vesicle and the subacrosomal cone. (C-F) Successive transverse sections through the acrosome. Note that anteriorly, in $\mathrm{C}$, the acrosome appears depressed, while posteriorly, in $\mathrm{D}-\mathrm{F}$, it is more circular. An electron-lucent layer $\left({ }^{*}\right)$ between the acrosome vesicle and the subacrosome cone may be observed in $D-F$. (G) Transverse section through the nucleus showing lacuna. $(\mathrm{H})$ Longitudinal section through the acrosome showing its flattened apical region and the well-developed epinuclear lucent zone. Note the space between the condensed chromatin and the nuclear membrane, occupied by a granular material. An 
arrowhead and an arrow indicate the nuclear shoulders and the membranous flange, respectively. a: acrosome vesicle; et: epinuclear lucent zone; 1, nuclear lacuna; n: nucleus; p: perforatorium; sc: subacrosomal cone. Scale bar $0.2 \mu \mathrm{m}$.

\section{Neck region}

The neck region connects the tail with the sperm head. This region consists of two centrioles, an extensive deposit of pericentriolar material, and the first ring of dense bodies (Figs $3 \mathrm{~A}, \mathrm{H}-\mathrm{I} \& 5 \mathrm{~A}, \mathrm{I}$ ). The proximal centriole is positioned centrally, parallel to the base of the nucleus, and presents a central, electron-dense structure in its interior (Figs $3 \mathrm{H} \& 5 \mathrm{~A}, \mathrm{I}$ ). The distal centriole constitutes the basal body of the flagellum. It lies perpendicular to the proximal centriole and extends caudally through approximately two-thirds of the midpiece, continuing with the axoneme. The distal centriole consists of nine triplets of microtubules. A peripheral dense fibre (coarse fibre) is associated with each of the nine triplets of the distal centriole (Figs $3 C \& 5 C)$. In both species, a pair of central microtubules extends into the transitional region between the distal centriole and the axoneme, and a dense structure, presumably a fibre, appears connecting triplet 3 with one of the central microtubules. Both centrioles are enclosed within a homogeneously dense material, the pericentriolar material that conforms in shape to the nuclear fossa. This material extends posteriorly between the two centrioles and contacts the anterior portion of the distal centriole, continuing as the dense peripheral fibers longitudinally (Figs $3 \mathrm{~A}, \mathrm{H} \& 5 \mathrm{~A}, \mathrm{I}$ ).

\section{Midpiece}

The midpiece is approximately $2.8 \mu \mathrm{m}$ long and is much shorter than the head. It consists of a single layer of mitochondria, interposed between rings of dense bodies, which encircles the anterior portion of the flagellum, including the neck region. The flagellum is formed by the axoneme, extending throughout the remaining length of the spermatozoon. It is organized in the usual 9+2 microtubules pattern, surrounded by nine peripheral fibres. These peripheral fibres rapidly decrease in diameter along the axoneme, with the exception of fibres at doublets 3 and 8 , which are thicker than the others, double, and detached from their doublets (Figs 3D-F \& 5D-F). A fibrous sheath, which surrounds the axoneme, extends into the midpiece to just posterior of the distal centriole (Figs. 3A; 5A, J). In longitudinal section it appears as regularly spaced, approximately square dense blocks connected by the longitudinal peripheral fibers at doublets 3 and 8 . The mitochondria are elongate columnar structures, with longitudinal cristae, and surround the distal centriole and fibrous sheath (Figs $3 A$ \& 5A, J). In cross section, they appear irregularly shaped, and usually 5 to 6 are seen around the axoneme 
(Figs 3D \& 5D-E). In the two species, the mitochondrial sheath is interspersed by dense bodies, which are not limited by a membrane, and are composed of a granular dense material identical to the pericentriolar material. However, they appear less electrondense than the mitochondrial sheath (Figs 3A, C, E, I \& 5A, E, J). Dense bodies are arranged in three ring structures, separated from each other by portions of mitochondrial columns (Figs 3A, I \& 5A, J) symbolized as $\mathrm{rs} 1 / \mathrm{m} 1, \mathrm{rs} 2 / \mathrm{m} 2, \mathrm{rs} 3 / \mathrm{m} 3$. The first ring of dense bodies adjoins the base of the nucleus. The second ring structure often appears only on one side in longitudinal section (Figs $3 \mathrm{~A}, I \& 5 \mathrm{~A}, \mathrm{~J}$ ) and is often interrupted by mitochondria in transverse section (Figs $3 \mathrm{C} \& 5 \mathrm{E}$ ). This suggests that this structure forms a semicircular ring. The third ring structure forms a closed ring (Figs 3E \& 5F), appearing in longitudinal section as kidney-shaped structures on each side of the fibrous sheath (Figs $3 A \& 5 A, J)$. Occasionally, mitochondria are present lateral to this ring structure (Fig. 3E). At the distal extremity of the midpiece, a small dense ring, the annulus, with an irregular, oval cross section, defines the terminus of the midpiece (Figs $3 A-B \& 5 A-B$, J).

\section{Principal piece}

The principal piece constitutes the tail of the spermatozoon. It extends posteriorly from the annulus and is formed by the axoneme surrounded by the fibrous sheath and the plasma membrane. In its anterior portion, there is a short region in which a thin zone of finely granular cytoplasm is observed between the fibrous sheath and the plasma membrane (Figs $3 B, F \& 5 B, G)$. Posteriorly, the plasma membrane becomes closely attached to the fibrous sheath (Figs $3 G$ \& $5 G$ ).

\section{Endpiece}

The very slender tail of the spermatozoon, posterior to the termination of the fibrous sheath, is referred to as the endpiece. In Tropidurus torquatus, the $9+2$ pattern in this region becomes disarrayed and the doublets break apart into singlets (Fig. $5 \mathrm{H}$ ), whereas in $\mathrm{T}$. semitaeniatus the pattern of microtubules is apparently maintained, although its diameter becomes reduced (Fig. 3G). 


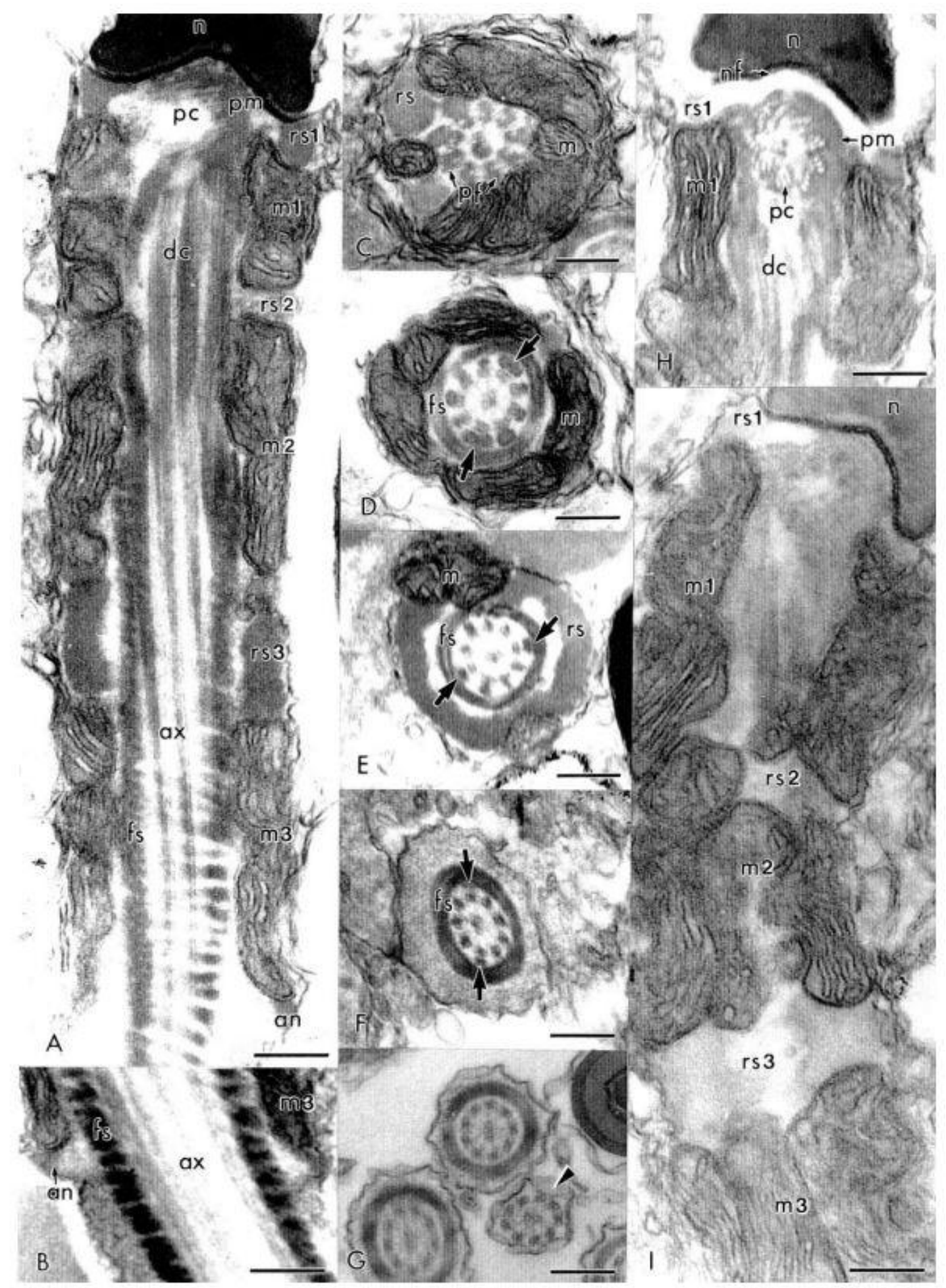

Fig. 3 Tropidurus semitaeniatus. (A). Longitudinal section of the posterior end of the nucleus and the midpiece. (B) Transition region between the midpiece and the principal piece. (C) Transverse section through the distal centriole showing the pair of microtubules and the dense material within it. (D) Transverse section through the axoneme showing the fibrous sheath and the nine peripheral fibres associated with the doublets. Note that the peripheral fibres at 3 and 8 (arrows) are double and detached from their doublets. (E) Transverse section through the third ring structure at the posterior portion of the midpiece showing the peripheral fibres at 3 and 8 (arrows) thicker than the others and detached from their doublets. (F) Transverse section through the anterior portion of the principal piece. (G) Transverse section of the posterior portion of the principal piece and the end piece (arrowhead). (H) Detail of the neck region. (I) Longitudinal section through the midpiece showing three ring structures 
separated by three sets of columnar mitochondria. an: annulus; ax: axoneme; dc: distal centriole; fs: fibrous sheath; m: mitochondria; $n$ : nucleus; nf: nuclear fossa; pc: proximal centriole; pf: peripheral fibres; pm: pericentriolar material; rs: ring structure. Scale bar $0.2 \mu \mathrm{m}$.

\section{Discussion}

In Tropidurus semitaeniatus and T. torquatus, the acrosome complex forms a tripartite pattern (acrosome vesicle, subacrosomal cone and the constricted nuclear tip), a plesiomorphic condition of tetrapods (Jamieson, 1995a). The following features, regarded as plesiomorphic in amniotes (Jamieson, 1995a), are also present in the two species: nucleus elongate; distal centriole extending through midpiece, penetrated by two central singlets from the axoneme; several mitochondria in cross-section of midpiece; annulus present; nine peripheral fibres associated with the nine doublets of the axoneme; peripheral fibres adjacent to doublets 3 and 8 enlarged, forming a double structure detached from their respective doublets. Tropidurus semitaeniatus and T. torquatus have a number of character-states considered synapomorphies of Squamata (Jamieson, 1995b): perforatorium single, wholly prenuclear; endonuclear canal absent; epinuclear lucent zone present; mitochondrial cristae linear; intermitochondrial dense bodies present; fibrous sheath extending into midpiece; and nuclear shoulders rounded.

A suite of character-states present in mature spermatozoa of tropidurids is also seen in the chamaeleonids Bradypodion karrooicum (Jamieson, 1995b) and Pogona barbata (Oliver et al., 1996): apical portion of acrosome in transverse section depressed; perforatorial base plate absent (questionably present in P. barbata); epinuclear lucent zone clearly defined and well developed; midpiece short (moderately long in B. karrooicum); dense bodies forming regular rings, regularly separated from each other by mitochondria (dense bodies more scattered in B. karrooicum). Tropidurus semitaeniatus and T. torquatus share with the polychrotid Polychrus acutirostris (Teixeira et al., 1996b) the following features: apical portion of acrosome in transverse section depressed; acrosome vesicle homogeneous and electron-dense; subacrosomal cone filled with an unevenly arranged matrix, instead of a paracrystalline structure; nucleus with interspersed lacunae; epinuclear lucent zone well developed; a finely granular material dispersed between the condensed chromatin and the nuclear envelope; midpiece short; dense bodies without their own membrane; mitochondrial matrix more electron-dense than dense bodies. The account by Furieri (1974) on the polychrotid Pristidactylus (-Cupriguanus) scapulatus permits only limited comparisons with our results: the midpiece is short as in tropidurids. 
Likewise, only limited comparisons are possible with the tropidurids studied by Furieri (1974): in Liolaemus austromendocinus and Phymaturus flagellifer (-palluma), the midpiece is short as in Tropidurus, and only P. flagellifer has the arrangement of ring structures and mitochondria like Tropidurus. This account reveals two unusual features of tropidurids relative to other iguanians: the presence of an electron-lucent, unilateral ridge at the acrosome surface, and an epinuclear lucent zone bounded by a membrane. The subacrosomal material is not closely attached to the acrosomal vesicle, being separated on one side by an electronlucent layer. The lack of adherence can be explained by an uneven distribution of ionized groups on the surface of the inner membrane of the acrosome vesicle. This feature has been observed only in Amphisbaena alba (Teixeira et al., in press). The narrow chamber within the anterior limit of the subacrosomal cone, at the anterior end of the nucleus, is bounded by a membrane, suggesting that it can be a nuclear extension, with a small diameter. To the best of our knowledge, this feature has not been observed in any other squamate. Despite the presence of a membrane, we considered the chamber as an epinuclear lucent zone in this account.

The only published accounts on the sperm ultrastructure of Tropidurus are the papers by Cruz-Landim \& CruzHöfling (1977) and Cruz-Höfling \& Cruz-Landim (1978) on spermiogenesis. These works indicate that, in late spermatids of T. cf. torquatus, the fibrous sheath occurs posteriorly to the midpiece, the sperm head is not depressed, and dense bodies or ring structures are absent. In the mature spermatozoon of $\mathrm{T}$. semitaeniatus and $\mathrm{T}$. torquatus, however, the fibrous sheath penetrates into the midpiece to the level of $m 2$, the acrosome is depressed, and ring structures are present, separating sets of mitochondria. In 1987, the T. torquatus species complex was split into 11 taxa (Rodrigues, 1987) and, without precise locality data and/or the re-examination of specimens, it is impossible to determine the current taxonomic status of the material studied by Cruz-Landim \& Cruz-Höfling (1977) and Cruz-Höfling \& Cruz-Landim (1978). It is possible that the differences reported above between T. semitaeniatus and T. torquatus and the species studied by those authors reflect taxonomic differences, i.e. the Tropidurus studied by Cruz-Landim \& Cruz-Höfling (1977) and Cruz-Höfling \& Cruz-Landim (1978) was not T. torquatus, but a related species within the same species group. A phylogenetic analysis of Tropidurus based on osteology, squamation, color, and hemipenes suggests that $\mathrm{T}$. semitaeniatus is a closer relative of $\mathrm{T}$. torquatus than other members of the T. torquatus group (Frost, 1992). 


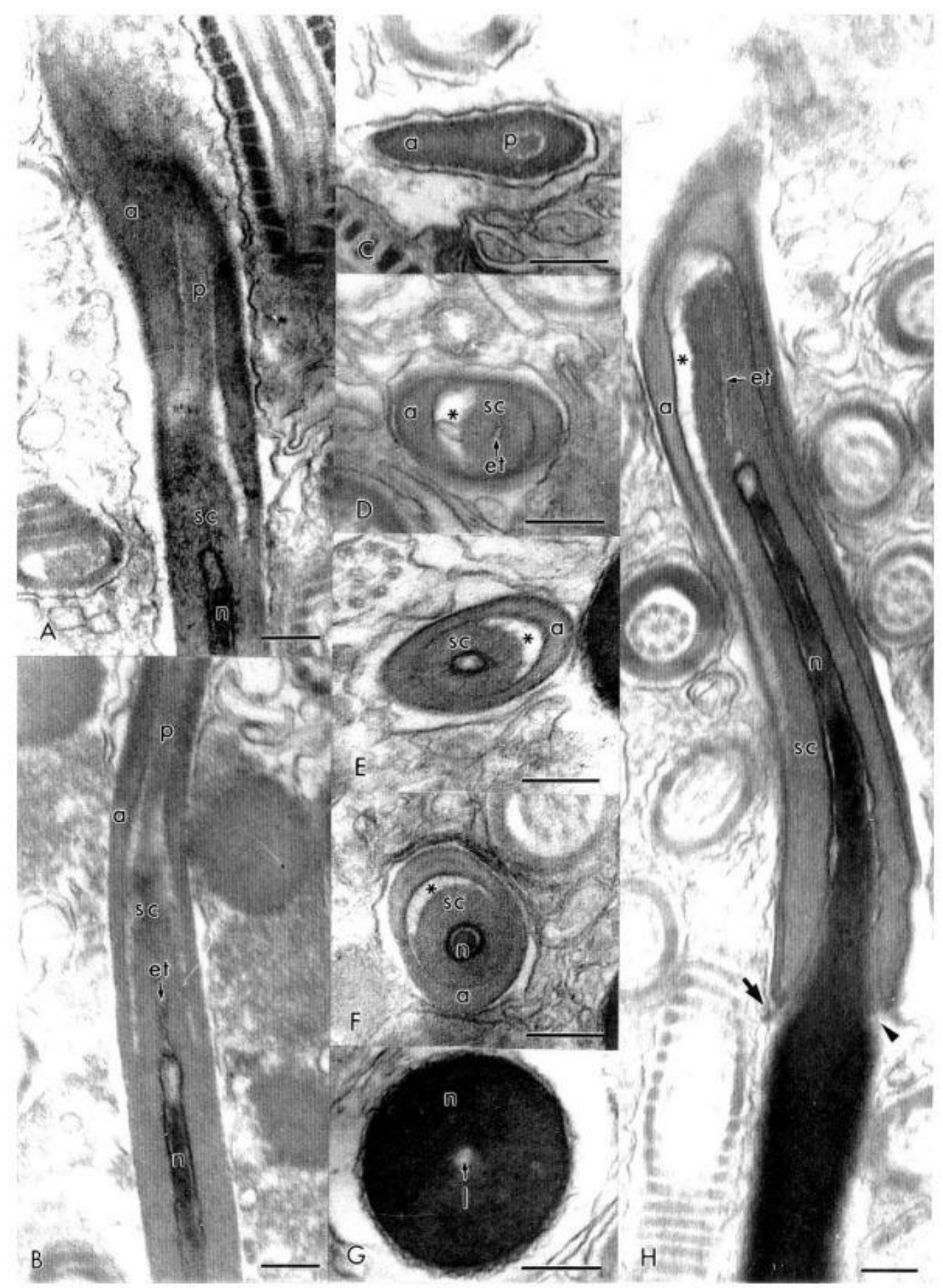

Fig. 4 Tropidurus torquatus. (A) Longitudinal section through the apical end of the acrosome showing its flattened portion and the perforatorium. (B) Longitudinal section through the acrosome showing the nuclear tip, the epinuclear lucent zone and the perforatorium. Note the space between the condensed chromatin and the nuclear membrane, occupied by a granular material, at the nuclear tip. (C-F) A series of transverse section through the acrosome. Note that anteriorly, in $\mathrm{C}-\mathrm{E}$, the acrosome appears very depressed, while posteriorly, in $\mathrm{F}$, it is more circular. An electron-lucent layer $\left({ }^{*}\right)$ between the acrosome vesicle and the subacrosome cone may be observed in D-F. (G) Transverse section through the circular nucleus showing lacuna. $(\mathrm{H})$ Longitudinal section through the basal region of the acrosome showing the electron-lucent ridge $\left({ }^{*}\right)$ between the acrosome vesicle and the subacrosomal cone. Note the nuclear shoulders (arrowhead) and the membranous flange (arrow). a: acrosome vesicle; et: epinuclear lucent zone; 1, nuclear lacuna; n: nucleus; p: perforatorium; sc: subacrosomal cone. Scale bar $0.2 \mu \mathrm{m}$. 
Alternatively, the differences between $T$. cf torquatus, $T$. torquatus and $T$. semitaeniatus might reflect structural changes resulting from the maturation process during epididymal transit. Spermatozoa functionally immature undergo structural, biochemical, and functional changes during epididymal transit (Bedford \& Nicander, 1971; Bedford, 1975; Orgebin-Crist, 1981; Carcupino et al., 1989), often completing maturation in the female reproductive tract as an adaptation to prevent premature acrosomal reactions during storage (Newton \& Trauth, 1992). In this way, epididymides act not only as sperm storage organs, but also as sites of maturation (Healy \& Jamieson, 1994). We strongly suggest that specimens should be deposited in accessible scientific collections and collection identification numbers should be provided in publications, enabling the reexamination of specimens in case of taxonomic changes. Further, mature, epididymal spermatozoa should preferentially be described.

The congeneric lizards Tropidurus semitaeniatus and $T$. torquatus are practically identical with respect to the ultrastructure of mature sperm cells. They differ in details such as degree of acrosome flattening, presence of bulging at nuclear base, and arrangement of microtubules in the endpiece. Differences in sperm ultrastructure characters of reptiles have been reported at the level of orders and families (Jamieson, 1995a; 1995b), suggesting that they can be useful in phylogenetic analyses. Nevertheless, the existence of major areas of disagreement between phylogenetic hypotheses derived from spermatozoa ultrastructural characters and gross morphological characters, led Teixeira et al. (1999a) to suggest that the intra-familial variability in these characters may be higher than currently thought. That seems to be the case within Chamaeleonidae (Jamieson, 1995b; Oliver et al., 1996), Scincidae (Jamieson \& Scheltinga, 1994; Jamieson, 1995b; Jamieson et al., 1996), and Tropiduridae. Further studies investigating the degree of variability in sperm ultrastructure characters across taxonomic categories might aid in clarifying at which taxonomic level they can be most profitably used in phylogenetic analysis.

A variety of characters derived from the sperm ultrastructure of squamates can profitably be used in phylogenetic analyses, where other datasets are uninformative (Teixeira et al., 1999a). Additional work describing the sperm ultrastructure of the families Corytophanidae, Crotaphytidae, Hoplocercidae, Iguanidae, Opluridae, and Phrynosomatidae (Frost \& Etheridge, 1989) are warranted and may cast light on the phylogenetic relationships of iguanians. 
ACKNOWLEDGEMENTS We thank Ayrton K. Péres Jr for invaluable assistance during field work, and an anonymous reviewer for insightful criticisms. The study was supported by CAPES, CNPq and FAPDF.

REFERENCES

Al-Hajj, H., Janakat, S. and Mahmoud, F. 1987. Electron microscopic study of sperm head differentiation in the lizard Agama stellio. Can. J. Zool., 65, 2959-2968.

Bedford, J.M. 1975. Maturation, transport and fate of spermatozoa in the epididymis. In: Astwood, E.B and Greep, R.O. (eds) Handbook of Physiology. Endocrinology V. American Physiological Society, Bethesda, Maryland, 303-317.

Bedford, J.M. and Nicander, L.N. 1971. Ultrastructural changes in the acrosome and sperm membranes during maturation of spermatozoa in the testis and epididymis of the rabbit and monkey. J. Anat., 108, 527-543.

Carcupino, M., Corso, G. and Pala, M. 1989. Spermiogenesis in Chalcides ocellatus tiligugu (Gmelin) (Squamata, Scincidae): an electron microscope study. Boll. Zool., 56, 119-124.

Clark, A.W. 1967. Some aspects of spermiogenesis in a lizard. Amer. J. Anat., 121, 369-400.

Cruz-Höfling, M.A. and Cruz-Landim, C. 1978. The fine structure of nuclei during spermiogenesis in the lizard Tropidurus torquatus (Lacertilia). Cytologia, 43, 61-68.

Cruz-Landim, C. and Cruz-Höfling, M.A. 1977. Electron microscope study of lizard spermiogenesis in Tropidurus torquatus. Caryologia, 30, 151-162.

Dehlawi, G.Y. and Ismail, M.F. 1990. Studies on the ultrastructure of the spermiogenesis of Saudian reptiles. 1. The sperm head differentiation in Uromastyx philbyi. Proc. Zool. Soc. A.R. Egypt, 21, 79-89.

Dehlawi, G.Y., Ismail, M.F. and Saleh, A.M. 1990. Studies on the ultrastructure of the spermiogenesis of Saudian reptiles. 2. The sperm tail differentiation in Uromastyx philbyi. Proc. Zool. Soc. A.R. Egypt, 21, 91-101.

Dehlawi, G.Y., Ismail, M.F., Hamdi, S.A. and Jamjoom, M.B. 1992. Ultrastructure of spermiogenesis of Saudian reptiles. 6. The sperm head differentiation in Agama adramitana. Arch. Androl., 28, 223-234.

Frost, D.R. 1992. Phylogenetic analysis and taxonomy of the Tropidurus group of lizards (Iguania: Tropiduridae). Amer. Mus. Novitates 3033, 1-68.

Frost, D.R. and Etheridge, R. 1989. A phylogenetic analysis and taxonomy of iguanian lizards (Reptilia: Squamata). Misc. Publ. Mus. Nat. Hist. Univ. Kansas, 81, 1-65.

Furieri, P. 1974. Spermi e spermatogenesi in alcuni iguanidi argentini. Riv. Biol. 67, 233-279. 
Healy, J.M. and Jamieson, B.G.M. 1994. The ultrastructure of spermatogenesis and epididymal spermatozoa of the tuatara Sphenodon punctatus (Sphenodontia, Amniota). Phil. Trans. R. Soc. London B, 344, 187-199.

Ismail, M.F., Dehlawi, G.Y. and Jalalah, S.M. 1995. Studies on the ultrastructure of the spermiogenesis of Saudian reptiles. 7. The sperm tail differentiation in Agama adramitana. J. Egypt. Ger. Soc. Zool., 16, 169-183.

Jamieson, B.G.M. 1995a. Evolution of tetrapod spermatozoa with particular reference to amniotes. In: Jamieson, B.G.M., Ausio, J. and Justine, J. (eds) Advances in Spermatozoal Phylogeny and Taxonomy. Muséum National d'Histoire Naturelle, Paris, 343-358.

Jamieson, B.G.M. 1995b. The ultrastructure of spermatozoa of the Squamata (Reptilia) with phylogenetic considerations. In: Jamieson, B.G.M., Ausio, J. and Justine, J. (eds) Advances in Spermatozoal Phylogeny and Taxonomy Muséum National d'Histoire Naturelle, Paris, 359-383.

Jamieson, B.G.M., Oliver, S.C. and Scheltinga, D.M. 1996. The ultrastructure of spermatozoa of Squamata. I. Scincidae, Gekkonidae and Pygopodidae (Reptilia). Acta Zool., 77, 85-100.

Jamieson, B.G.M. and Scheltinga, D.M. 1994. The ultrastructure of spermatozoa of the Australian skinks, Ctenotus taeniolatus, Carlia pectoralis and Tiliqua scincoides scincoides (Scincidae, Reptilia). Mem. Queensland Mus., 37, 181-193.

Newton, D.W. and Trauth, S.E. 1992. Ultrastructure of the spermatozoon of the lizard Cnemidophorus sexlineatus (Sauria: Teiidae). Herpetologica, 48, 330-343.

Oliver, S.C., Jamieson, B.G.M. and Scheltinga, D.M. 1996. The ultrastructure of spermatozoa of Squamata. II. Agamidae, Varanidae, Colubridae, Elapidae, and Boidae (Reptilia). Herpetologica, $52,216-241$.

Orgebin-Crist, M.L. 1981. Epididymal physiology and sperm maturation. Prog. Reprod. Biol., 8, 80-89.

Rodrigues, M.T. 1987. Sistemática, ecologia e zoogeografia dos Tropidurus do grupo Torquatus ao sul do Rio Amazonas (Sauria, Iguanidae). Arq. Zool., S. Paulo, 31, 105-230.

Saita, A., Comazzi, M. and Perrotta, E. 1988. New data at the E.M. on the spermiogenesis of Iguana delicatissima (Laurent) involving comparative significance. Acta Embryol. Morphol. Exper. n.s., 9, 105-114.

Stanley, H.P. 1971. Fine structure of spermiogenesis in the elasmobranch fish Squalus suckleyi. J. Ultrastr. Res., 36, 86-102.

Teixeira, R.D., Colli, G.R. and Báo, S.N. 1999a. The ultrastructure of the spermatozoa of the lizard Micrablepharus maximiliani (Squamata, Gymnophthalmidae), with considerations on the use of sperm ultrastructure characters in phylogenetic reconstruction. Acta Zool., 80, 47-59.

Teixeira, R.D., Colli, G.R. and Báo, S.N. 1999b. The ultrastructure of spermatozoa of the lizard Polychrus acutirostris (Squamata, Polychrotidae). J. Submicr. Cytol. Pathol. 31 (in press). 
Wiens, J.J. 1998. The accuracy of methods for coding and sampling higher-level taxa for phylogenetic analysis: a simulation study. Syst. Biol., 47, 397-413. 